Владимир Баровић

УДК 070:929 Антић М.

Филозофски факултет Универзитета у Новом Саду

821.163.41.09 Антић М.

barovic@neobee.net

\title{
ЗНАЧАЈ МИРОСЛАВА АНТИЋА ЗА СТРУКТУРАЛНО РАЗУМЕВАЮЕ НОВИЈЕГ ПЕРИОДА У РАЗВОЈУ СРПСКОГ НОВИНАРСТВА
}

Велики песник Мирослав Антић читав радни век бавио се новинарством, где је остао упамћен по особитом прегалаштву на покретању и уређивању часописа. Антић је оставио значајан траг на пољу репортаже и интервјуа, који се сматрају најзахтевнијим новинарским жанровима. У раду се анализира значај Мирослава Антића за развој новије српске журналистике и то у домену жанра, слободе израза и тематског опуса. Посебно се анализира избор тема које Антић обрађује, снага његовог новинарског израза, и посебан журналистички сензибилитет, који је на граници са уметношћу.

Кључне речи: Мирослав Антић, новинарство, жанрови, структуралност, анализа, српска журналистика.

\section{УВОДНО РАЗМАТРАњЕ}

Мирослав Антић је занимљива и интригантна појава на југословенском уметничком небу, јер је један од ретких послератних представника српског новинарства који се може сврстати у ред наших највећих песника. Са завршетком Другог светског рата, као да се прекинула невидљива „златна нит“ српских журналиста који су били врсни писци и песници, попут Милоша Црњанског који је емигрирао, Радета Драинца који је за време рата преминуо и низ других новинара-уметника, које је ратна бујица заувек склонила са медијске сцене. Антић је као младић ушетао на велика врата у свет српске и југословенске поезије, и у њему ће остати упамћен као аутор најлепших песама за младе, које улазе у све новије антологије и школске лектире. Од „Плавог чуперка“ до 
поеме „Војводина“, Мирослав Антић је показао да је песник који је за живота стекао велику славу и признања, и упркос томе остао веран младалачким идеалима. По сопственом казивању бавио се разним пословима: од физичког радника, дрводеље, боксера и морнара, до позоришног редитеља, драматурга и филмског режисера, али је увек остао доследан себи као песник и стваралац. Поред новинарства и песништва, активно се бавио сликарством и филмом, што је овенчано и престижним наградама, али је упркос слави избегао замку уласка у апарат партијске власти, у коју су пали многи уметници, његови савременици. Иако је код нас упамћен као велики песник, Антић је читавог живота био врстан журналист, који је пензију дочекао у новосадском „Дневнику“; писао је у дневним листовима, био је духовни творац и покретач музичког магазина „Ритам“, уредник је дечјих часописа, објављује песме и текстове у часописима који се баве уметношћу и културом. Антић је по сведочењу пријатеља и добрих познавалаца његовог живота, био управо опчињен новинарским позивом и оним што тај „занат“ пружа ономе ко му се искрено преда. Иако је био чувен као човек са харизмом, који је могао за трен да опчини саговорника, он је нашем новинарству и будућим новинарима оставио низ репортажа, прича, интервјуа и другог материјала који казује да је тај бард, достигао не само песничке, већ и новинарске висине.

Антић је био занимљив и интригантан новинар који се интересује за низ различитих проблема и питања, јер знао је много о галаксијама, занимао га је фудбал, лично је познавао Превера, али му ништа људско није било страно, те је добио епитет највећег боема нашег новинарства. Анегдоте о његовим бесаним ноћима, зачињеним вином, дуванским димом и звуком тамбурица, и дан данас радо се препричавају у веселим новинарским круговима. Антић је као структурална и свестрана личност стизао да оде на далека путовања, ради као новинар „Дневника“, буде настављач и уредник чика Јовиног „Невена“, из три брака имао је шесторо деце, а младим поколењима оставио је низ песама непролазне вредности. Иза њега је остала импозантна библиографија од преко три хиљаде одредница и преко сто педесет издања његових књига! На почетку рада који у фокусу има новинарство тог песника-журналисте, треба навести шта сам Мирослав Антић мисли о свом животопису: „У ствари, ја свима кажем 
да праву биографију, онакву какву бих желео, још немам, и поред толико књига које сам написао, слика које сам излагао, филмова које сам снимио, драмских текстова, репортажа у новинама... Сваког јутра пожелим да почнем једну одличну биографију, која би послужила, ако ником другом, бар ђацима у школи, јер они, нажалост, морају да уче и живот писца... Највише бих волео да сами измислите моју биографију. Онда ћу имати много разних живота и бити најживљи међу живима““( Антић 2008)ํ.

\section{ЖИВОТОПИС}

Мирослав Антић рођен је 14. марта 1932. године у Мокрину, селу удаљеном десетак километара од Кикинде, где је као учитељ службовао Микин отац Ненко, који је пореклом из источне Србије. Мајка Меланија била је из богате породице Јовановић, која је после Првог светског рата на основу споразума о размени становништва, дошла из Мађарске. Мали Мирослав је одрастао у мајчиној породици код бабе и деде, на салашу који ће му увек остати у живом сећању, а равница и њено мистично пространство, биће чест мотив његових песничких надахнућа, али и новинарских текстова. Антић је основну школу похађао у Кикинди, а породица се од пролећа 1941. године преселила у Панчево, где је наставио образовање.

Другог светског рата, који је преживео као дете, Антић се доцније сећао у својим делима, која упечатљиво сведоче о нацистичким злочинима, убиствима, депортацијама и страшним прогонима. У Панчеву, Антић ће завршити гимназију, где је по први пут показао песнички таленат, којим ће се доцније прославити, а прву песму „Мајка“, објавио је 1948. године. Исте године у лето, учествовао је као ђак на омладинској радној акцији на изградњи ауто пута „Братсво -јединство“, а био је и активни спортиста. Занимали су га борилачки спортови, бокс пре свега. У тој древној античкој вештини, потоњи поета и новинар имао је успеха, јер постао је јуниорски првак Војводине, а касније ће га занимати џудо. Своје синове доцније ће подстицати да се баве тим спортом.

Крајем четрдесетих година прошлог века, Антић је стасавао у маркантног младића, који се интересује за поезију, књижевност и позориште, а 1 
почетком лета 1950. године добија сведочанство о успешно положеној великој матури гимназије у Панчеву. Крајем те године изашла је прва књига Антићеве поезије „Испричано за пролећа“, чији уредник је био познати песник - Оскар Давичо, који је проницљиво осетио да се ради о будућем великану наше поезије.

Антић се у Панчеву први пут оженио младом и лепом ученицом Љубицом (девојачко Винети-Дошља), а 1954. године прелази из „Панчевца“ у „Дневник“, односно из Панчева долази у Нови Сад, град који постаје његов, и којем ће се из далеких путешествија увек одано враћати. У Матици српској објавио је другу збирку поезије „Плаво небо“, а ускоро излази и „Рожество твоје“, и са свега двадесет и две године рађа се афирмисани песник, који полако израста у барда српске поезије.

Антић је заволео Нови Сад, али га је новинарски ангажман на кратко одвео до Београда где прелази 1959. године, на место уредника дечјег листа „Пионири“. Није се дуго задржао у „Пионирима“, јер већ наредне године напушта редакцију и посвећује се писању, често путује и поново долази у Нови Сад, где се као новинар враћа на рад у „Дневник“. Антић се други пут оженио 1962. године са Светланом, са којом је имао четворо деце: Игора, Сању, Жењу и Бориса. У том пероди много радио као новинар, још више као песник и стваралац, о чему је за „НИН“, рекао: „Неко целог живота ради и пише. Неко целог живота држи придике шта би требало писати, а кад умре остану иза њега две-три свешчице. Ја сам увек више поштовао једног марљивог литерату него педесет потенцијалних генија који су до смрти остали само потенцијални генији““ (Пешић 2000 : 45-46).

Најпознатија збирка песама „Плави чуперак“, која ће га увести у ред бесмртника наше поезије, изашла је из штампе крајем 1965. године и Антића сврстала у ред најчитанијих песника послератне Југославије. Њега су ондашњи критичари прво одбацивали и маргинализовали, сматрајући ту збирку за неважну, а и на само објављивање, песник је дуго чекао. Сам Антић ће у разговору са новинарима много година касније рећи да је рукопис ове књиге годину и по дана стајао у фиокама издавача и да је добио шест негативних рецензија! (Пешић $2000: 66$ ).

Потоњи критичари Антића су поредили са Змај Јовом, јер одважио се да пише за младе и то за оне који су у пуберетском узрасту, када је узаврела 
младост пуна емоција, стрепњи, страхова и нада (Баровић 2009 : 49). У инат првобитним негативним рецензијама и одбијању Матице српске да штампа књигу, стихове „Плавог чуперка“ памте и рецитују све генерације, од изласка поеме до данас.

Свестран уметник, какав је био, није могао одолети изазову филма. Прво је режирао и урадио сценарио за документарац „Тројица из старог Сомбора“, а затим се дотакао тешких и озбиљних тема из ближе историје. У филму „Доручак са ђаволом“ који режира 1971. године бави се принудним откупом и колективизацијом, осетљиву тему Информбироа обрађује у остварењу „Свети песак“, а снимио је и филмове: „Широко је лишће“, „Споменик“, „Хајде да растемо“, „Страшан лав“. На Петроварадинској тврђави добио је 1967. године атеље који је био у очајном стању, али га је Антић вичан свакој врсти мануелног посла, лепо средио као уметнички кутак у ком је стварао.

Позната збирка песама „Гарави сокак“ излази 1973., а наредне године Антић се трећи и последњи пут жени, Смиљом (љиљом) Рајковац, са којом је имао два сина: Вука и Југа. Породица је прво живела у атељеу на тврђави, а затим је почетком осамдесетих година у новоизграђеном Авијатичарском насељу у предграђу Новог Сада, песник добио кућу у којој ће сачекати последње дане. То насеље је било чувено као дом многих наших уметника и стваралаца - музичара, вајара, писаца, сликара, песника, а по анегдоти је саграђено по Титовој директиви, након што се маршалу Антић пожалио да нема где да станује. Иако је тад живео на периферији града где га „тешко налазе и пријатељи и поштари“, Мирослав Антић је остао запамћен као човек који упркос слави и „титули“ популарног лица са тв екарана, воли дружење са обичним светом. Није то било позерско седење са „просечним смртницима“ демагогије ради, што данас редовно чине многи жељни славе, већ искрено дружење са људима, о чему је остало много ангедота, у којима Мика ћаска, шали се и дружи са обичним људима: месарима, чистачима, берберима. Најпријатније се осећао у кафани. Без обзира да ли је испијао вињак или мераклијски ужива у кафи, Антић је у том животном чворишту, непрекидном извору новинарских прича и галерији судбина, налазио инспирацију и утеху.

Боемски живот, велика пушачка страст или нешто треће, тек Антићево здравље је почетком осамдесетих година видно нарушено, и зато је превремено 
пензионисан почетком августа 1981. године. Иако је тешка болест узимала маха, чак је у јесен 1983. године доживео клиничку смрт, Антић је наставио да ствара и ради. Последњи дан у животу, уручена му је награда „Јован Поповић“ , коју је додељивао Савез бораца за животно дело. Мирослав Антић умро је 24. јуна 1986. године у Новом Саду.

\section{ПЕСНИК У НОВИНАРСКОМ КАПУТУ}

Новинарски почетак Антића везује за „Панчевац“, лист који је излазио још од 19. века и био веома читан и угледан у српском грађанству са друге стране Саве и Дунава. У поново покренутом послератном „Панчевцу“, који је излазио као недељни „лист Социјалистичког савеза радног народа“, као новинар-сарадник примљен је у јануару 1953. године Мирослав Антић, двадесетједногодишњи студент. Поред класичног новинарског посла он је још на почетку журналистичког ангажмана показао љубав према најмлађима, јер се прихвата уређивања дечје стране, што је чинио са полетом и ревношћу.

Ликовни таленат Антић је показао цртањем стрипа, „Бата из Баната“, који је био његова идеја, а у медијској историји је забележен као први стрип у локалним новинама у читавој Југославији. „Бата из Баната“ излазио је у листу из недеље у недељу, а на основу анализе утврдио сам да је у првим бројевима стајао мали потпис „Антић“, у горњем десном углу последње сличице стрипа. Духовит текст, сјајан цртеж, карактерни ликови и „Бата“ је брзо освојио читаоце у том суморном времену, раних педесетих. Тема Микиног стрипа су: раднички савети, немар сеоских учитеља, јавашлук у пошти, наредбе локалних власти, и многе друге друштвене теме. Као прави креативни стваралац, Антић мења „главу“ „Панчевца“, коју модернизује и стилизује тако да назив новина израња из панораме града, што је за оно време било веома модерно решење насловне стране.

У Панчевцу је Антић „испекао“ новинарски занат јер поред класичног журналистичког посла који је свакодневно обављао у редакцији, брзо се профилисао као врстан репортер. За разлику од униформисаних извештаја других новинара који следе административни стил партијских форума, Антић је иако млад по годинама, показао новинарску зрелост и слободу у избору тема. 
Он пише репортаже које зраче богатством језика, понекад налазимо емотивне набоје и снажне изразе који одају јаку личност, спремну да брани јавни интерес. При избору тема чест мотив су културне установе, а у тексту који доноси из градске библиотеке он пише: „Од шврће са образима руменим као јабуке, до старца који тражи „нешто са - крупнијим словима, јер слабо видим“...Соба је већ скоро полу празна. Ту и тамо преврћу се картони и бележе бројеви књига. Загрејано је. Пријатно. Тихо...Излазим. За мном иду два пионира и живо расправљају. До капије слушам њихово брбљање о путовању на месец, ракетном броду и чудним људима са Марса. Један од њих држи у руци књигу Жил Верна и одлазе низ улицу“ (Антић $1953: 2$ ).

У „Панчевцу“ Антић скоро редовно објављује своје песме, и у том листу пред читаоце излазе: „Насмејана песма“, „Белешка“, „Блада“, „Проповед“, „1944“. У својим репортажама, извештајима и цртицама, пише о уметности, изложбама и социјалним темама, али су у средишту његовог интересовања деца, ђаци, гимназијалци, пионири, они о којима ће доцније испевати најлепше песме на српском језику. У репортажи „Пред почетак школске године“, Антић као млад новинар топло пише о новом ђачком почетку, а живим речима слика како ће то изгледати када каже: „А кроз неколико дана, поново ће црне кецеље и качкети пролазити градским улицама, напуниће се разреди, поново ће у дневнику да се нижу петице и - двојке, звониће школско звонце и шарениће се двориште од граје и смеха““ Антић 1953a : 2).

Својим журанлситичким радом млади репортер је брзо прешао оквире локалног листа и зато упућује молбу новосадском „Дневнику“ да га приме у радни однос, а он би радио било шта. Чак се нудио да ако треба пакује и продаје новине, а Јован Виловац ондашњи уредник „Дневникове“ културне рубрике у лето 1954. године позвао је Антића, не да ради као колпортер, већ као новинар.

Антићев биограф Радован Поповић о Микином односу према новинарском позиву надахнуто пише: „Био је опчињен новинарством и та страст новинарска држаће га до краја живота: тај мирис штампарске боје, настанак новине, трагање за причом, дружење у редакцији даноноћно.... Мика је радио у листу Новосадски дневник који је излазио средом, као локално издање Дневника, све до 1959. године. Уредник му је био Љуба Милин... Писање у новинама га је омађијало“ (Поповић $2000: 31$ ). 
Са преласком у новосадски „Дневник“ Антић је дошао да живи у Нови Сад, а пошто је радакција била у згради некадашњег „Југословенског дневника“ код Бановине, Мика је редовно свраћао у оближњи ресторан „Ловац“ у зграду Ловачког савеза Војводине, која је била згодно смештена, тик уз редакцију. Прелазак у велики лист као што је био „Дневник“, пружио је младом журналисти нове могућности, упознавање старијих колега новинара од којих је уз сав свој таленат, имао шта да научи и да чује. У „Дневнику“ обрађује разне теме из области културе, што му као афирмисаном песнику није стварало тешкоће, али стара љубав према репортажи није пресахла. Новинарство Антићу пружа могућност да путује, креативно распоређује своје радно време, што он чини тако што по сопственом сведочењу 6 сати дневно посвећује журналистици, а остатак је резервисан за уметност и поезију. „Крећући се у свим временима и просторима, захваљујући новинарству и месту репортера у „Дневнику“, Антић је знао да каже - Све је створено из кретања, а ко се више креће него новинар. Захваљујући новинарству успео сам да обиђем цео свет, сем Аустралије. Наравно да тамо нисам само скупљао материјале за репортаже, него се ту врло много залепило за мене од других култура“ (Живановић 2008).

Као што је у својим песмама исказивао љубав према деци и омладини, тако је и у новинарском ангажману показао да га занимају најмлађи. У лето 1959. године из „Дневника“ је прешао у Београд где се прихвата места уредника недељног дечјег листа „Пионири“. У том дечјем информативном листу Мика је задужен за рубрику из културе који излази под називом „Ревија“. Иако је са пуно керативности уређивао своју културну рубрику, већ почетком наредне године Антић је напустио „Пионире“, незадовољан унутрашњим односима у редакцији и поново се вратио у Нови Сад, у „Дневник“.

Чини се да је неком чудном нити везан за тај лист јер у њему остварује највише новинарске домете, марљиво ради и пише репортаже, чланке, интервјуе, приказе, а његов суверен терен је културна рубрика. Радо се дружи са колегама новинарима, учествује на окупљањима које журналисти организују на разним местима, најчешће је у клубу „Дневника“. У том листу имао је низ рубрика које уређује, а читаоци их до наших дана памте по личном Антићевом печату, особеном стилу писања и лепоти казивања. „Био је изузетан репортер, а његове рубрике „Обично петком“, „Журнал Мирослава Антића“, „Галерија 
савременика“, читале су се са највећим интересовањем“ (Васиљевић 2008).

Посебно читан и цењен од публике био је „Журнал Мирослава Антића“ у ком је познати новинар обрађивао разне теме, опсервирао проблеме, износио своја запажања о људима, појавама и процесима у друштву. Када рецимо полемише о проблему бубашваба у новоизграђеним насељима на Лиману, Антић не пропушта прилику да напише: „, Сад сви ћуте, јер није отмено да се каже: газимо по бубама. Некоме стварно треба упутити писмо са жалбом. Пронаћи легла буба које се све више множе (на Пољопривредном факултету сазнали смо да им одговара температура коју даје централно грејање) и таманити их. А уз пут, ако се то може, ваља искоренити и друге невоље, друга загађења која се могу свести под бубашвабе“( Антић 1971 : 7). Када пише колумну на 8. март Антић се не бави тривијалним величањем жене, већ искрено и песнички надахнуто каже: „, Ја хоћу да продужим годину за жене. За мајке. Да им одам почаст. Да их пољубим у руку. Хоћу да тврдим да су оне 365 дана у нашој памети, овако уморне и радне као и ми, овако са свим нашим нервозама, а уз то, са својим платама, прањима судова, неговањем деце, трпљењем чекања да се вратимо, мрзовољни, џандрљиви, ми - мушкарци са прљавим кошуљама и главама које се три пута повећају од једне партије карата или пет вињака“ (Антић 1971a:1).

У новинарству се Антић одлично сналазио, инспирацију за писање налазио је у свакодневном животу, проблемима које људи имају, а стално је у џепу носао бележницу у којој је записивао детаље које ће касније обрадити, разложити и преточити у своју сталну рубрику. Новинарски посао је сматрао крајње озбиљним, напорним и одговорним, а и данашњим новинарима, посебно оним млађим који још брусе свој стил могу као узор послужити Антићеви текстови из рубрике „Журнал Мирослава Антића“.

\section{ЗАКЉУЧАК}

Иако је у великој мери проскрибован због боемског живота, Антић је сам разбио стереотип да даровити новинари могу да раде и када попију коју више. „Алкохол ми је јако одмогао у писању. Могу да сликам, да мешам боје, да понекада, као у магновењу, добијем најчудеснију технику за коју после нећу да кажем како је настала, али да пишем не могу. Имам утисак да сам написао 
нешто генијално, а кад се отрезним схватим да то није ништа“-искрено пише чувени боем и новинар (Поповић $2000: 161$ ).

Иако је добијао престижне награде за песништво, тек пред крај живота на предлог колега из „Дневника“ Антић је марта 1986. године добио награду за животно дело Друштва новинара Војводине. Иако није жудео за признањима и друштвеним почастима, Мика је жалио што уз друге признате уметнике није ушао у Војвођанску академију наука и уметности, и чак је уз Јована Солдатовића, Милана Коњовића, Драшка Ређепа и Ференца Фехера, одлучио да у знак протеста, оснују антиакадемију.

Антић је највећи траг у нашем новинарству сигурно оставио у репортажи која му је била омиљени жанр и на том пољу млади новинари од њега могу највише научити. „Антићево перо најлепше је сијало у репортажи: увек из живота и о њему, бојене речима песника, одмах препознатљив по раскошном перу и новинарском занату. С наднасловом „Обично петком“, Антић је у Дневнику објавио више стотина друштвених хроника и репортажа које су читаоци волели“ (Група аутора 1992 : 396). Мика је имао своју методологију која се састојала из записивања на парчиће хартије свих важних дешавања, момената, цртица које би затим ређао по столу, и од тога је сачињавао текст. Имао је слично Црњанском, обичај да своје реченице бруси до савршенства, да их глача, дотерује, а велики део текста би избацивао и дорађивао, што је био захтеван посао, јер радио је на хартији и писаћој машини. Његова реченица је кратка и јасна, без претераних и сложених конструкција. Када се враћао са многобројних путовања Антић је у својој бележници и на папирићима увек доносио материјал за рубрику, коју је са љубављу писао, склон старом новинарском обичају да се текст предаје у задњи час. „Репортажу мораш, како је пичао, да ископаш и отмеш из живота. У антологији најлепше југословенске новинарске речи, читалац би видео да је Антић био репортерски сјај и првак“ (Група аутора $1992: 396)$.

Тешко је пронићи у дубине уметничке душе, али је у Антићевом стилу приметна доза песничког надахнућа, поетске неспутаности у комуникацији новинар-читалац, што даје посебну нијансу његовим журналистичким текстовима. Он је као репортер и колумниста показао да велики новинар пише тако да га разуме и скромније образован читалац, иако је пуштао да се 
у новинарском капуту размахне песник. То је величина новинара Мирослава Антића, да тешке и озбиљне теме и друштвене дилеме саопшти на једноставан и лако разумљив начин. Тиме ће Антић ући и у антологију српског новинарства као велики журналистички учитељ, који генерацијама новинара показује како се пише о обичним људима и за обичне људе.

\section{ЛИТЕРАТУРА И ИЗВОРИ}

Антић, Мирослав (1953a). Пред почетак школске године. Панчевац. број 38: 2 .

Антић, Мирослав (1971). Бубашвабе долазе! Дневник. 02.03.1971:7.

Антић, Мирослав (1971а). Зашто један дан?, Дневник.08.03.1971:1.

Антић, Мирослав (1953). Сваког минута један посетилац. Панчеваи. број $13: 2$.

Антић, Мирослав (2008). Мирослав Антић о себи самом: http:// miroslavantic.blogspot.com/2008/08/miroslav-anti-o-sebi.html

Боаров, Димитрије - Баровић, Владимир (2011). Великани српске штампе. Београд: Службени гласник.

Баровић, Владимир (2009). Велики песник, издавач и новинар - Јован Јовановић Змај. Линк. 78: 48-50.

Васиљевић, Бошко (2008). Живот се учи од људи, а не из књига: http:// www.vm.rs/index.php/prethodna-web-izdanja-vm/vojvodjanski-magazin-broj02/268-ivot-se-ui-od-ljudi-a-ne-iz-knjiga

Ређеп, Драшко (1992). Антологија Антић, Изабрана лирика Мирсолава Антића. Нови Сад : Прометеј.

Дневник

Ређеп, Драшко (2008). Којих нема. Вршац: Књижевна општина Вршац.

Група аутора (1992). Два века српског новинарства. Београд: Институт за новинарство.

Панчевац

Поповић, Радован (2000). Антић њим самим. Нови Сад: Прометеј.

Живановић, Милан (2008). Уместо руже на његовом гробу: http:// miroslavantic.blogspot.com/2008/08/umesto-rue-na-njegovom-grobu.html 
Vladimir Barović

THE IMPORTANCE OF MIROSLAV ANTIĆ FOR STRUCTURAL UNDERSTANDING OF THE RECENT PERIOD IN DEVELOPMENT OF SERBIAN JOURNALISM

\begin{abstract}
Summary
A great Serbian poet Miroslav Antić was also a journalist, and he is remembered for his efforts on starting and editing magazines. He left his mark in the field of reportage and interview, which are considered to be the most demanding journalism genres. This paper analyzes the importance of Miroslav Antić for the development of contemporary Serbian journalism in the domains of genre, freedom of expression and theme corpus. A special attention is paid to the choice of topics Antić worked on, the power of his journalistic expression and a special journalistic sensibility which verged on art.
\end{abstract}

Key words: Miroslav Antić, journalism, genres, structure, analysis, Serbian journalism. 